\title{
CONCERNING THE ROLE OF ARTERIAL BARORECEPTORS IN THE CONTROL OF ALDOSTERONE SECRETION
}

\author{
By CHARLES C. J. CARPENTER, JAMES O. DAVIS AND CARLOS R. AYERS \\ WITH THE SURGICAL ASSISTANCE OF ALFRED CASPER \\ (From the Section on Experimental Cardiovascular Disease, Laboratory of Kidney and \\ Electrolyte Metabolism, National Heart Institute, Bethesda, Md.)
}

(Submitted for publication January 12, 1961 ; accepted February 17, 1961)

Since the suggestion by Epstein, Post and McDowell (1) that renal conservation of $\mathrm{Na}$ is conditioned by the degree of filling of some portion of the arterial tree, various investigators $(2,4-6)$ have presented conflicting data concerning the role of arterial baroreceptors in the control of aldosterone secretion. Barger, Muldowney and Liebowitz $(3,5)$ have suggested that the moderator reflex, of which baroreceptors in the carotid sinus and the aortic arch constitute the afferent limb, may lead to both increased sympathoadrenal tone and hypersecretion of aldosterone in experimental congestive heart failure. Bartter, Gann and Mills $(2,6)$ have reported that baroreceptors located in the thyrocarotid arterial junction provide the afferent limb of the nervous mechanism that leads to hypersecretion of aldosterone after thoracic inferior vena caval constriction in the dog. Davis, Yankopoulos and Holman (4) have found that neither carotid sinus denervation nor subsequent bilateral vagotomy prevented the increased uri- nary aldosterone excretion and the virtually complete $\mathrm{Na}$ retention observed in dogs with ascites secondary to thoracic inferior vena caval constriction. The present study was designed to examine the hypothesis that arterial baroreceptors play an essential role in the regulation of aldosterone secretion.

\section{METHODS}

Experiment 1 consisted of chronic studies aimed to determine the effects of denervation of baroreceptor areas, singly and severally, upon the hypersecretion of aldosterone and the marked $\mathrm{Na}$ retention which result from chronic thoracic inferior vena caval constriction. All experiments were performed on $15-$ to $20-\mathrm{kg}$ mongrel dogs. Each animal was kept in a metabolic cage throughout the experiment and received (by forced feeding when necessary) a synthetic diet containing $60 \mathrm{mEq}$ of $\mathrm{Na}$ and $18 \mathrm{mEq}$ of $\mathrm{K}$ per day. All animals were allowed water ad lib. Urinary and fecal $\mathrm{Na}$ and $\mathrm{K}$ excretions were determined by flame photometry throughout all experiments. Inferior vena caval pressures were measured with a water manometer. Ascites was removed by paracentesis at frequent intervals. In the animals in which

TABLE I

Effects of thoracic inferior vena caval constriction on electrolyte excretion in dogs with bilateral denervation of the common carotid arteries, the carotid sinuses and the thyrocarotid arterial junctions

\begin{tabular}{|c|c|c|c|c|c|c|c|c|c|c|}
\hline \multicolumn{6}{|c|}{ After carotid denervation and before caval constriction } & \multicolumn{5}{|c|}{$\begin{array}{l}\text { After carotid denervation plus thoracic inferior } \\
\text { vena caval constriction }\end{array}$} \\
\hline \multirow[b]{2}{*}{ Dog } & \multicolumn{2}{|c|}{ Na excretion } & \multicolumn{2}{|c|}{ K excretion } & \multirow{2}{*}{$\begin{array}{l}\text { Fecal } \\
\mathrm{Na} / \mathrm{K}\end{array}$} & \multicolumn{2}{|c|}{$\mathrm{Na}$ excretion } & \multicolumn{2}{|c|}{$\mathrm{K}$ excretion } & \multirow{2}{*}{$\begin{array}{l}\text { Fecal } \\
\mathrm{Na} / \mathrm{K}\end{array}$} \\
\hline & Urine & Feces & Urine & Feces & & Urine & Feces & Urine & Feces & \\
\hline & \multicolumn{2}{|c|}{$m E q / d a y$} & \multicolumn{2}{|c|}{$m E q / d a y$} & & \multicolumn{2}{|c|}{$m E q / d a y$} & \multicolumn{2}{|c|}{$m E q / d a y$} & \\
\hline 1 & $\begin{array}{c}55.2 \\
{[7]^{*}}\end{array}$ & $\begin{array}{r}4.0 \\
{[6]}\end{array}$ & 25.6 & 0.7 & 5.7 & $\begin{array}{c}2.2 \\
{[9]}\end{array}$ & $\begin{array}{c}1.0 \\
{[9]}\end{array}$ & 17.5 & 8.1 & 0.1 \\
\hline 2 & $\begin{array}{r}57.8 \\
{[5]}\end{array}$ & $\begin{array}{l}3.1 \\
{[5]}\end{array}$ & 18.3 & 1.1 & 2.8 & $\begin{array}{r}2.5 \\
{[7]}\end{array}$ & $\begin{array}{c}0.6 \\
{[7]}\end{array}$ & 32.9 & 7.0 & 0.1 \\
\hline 3 & $\begin{array}{r}52.4 \\
{[7]}\end{array}$ & $\begin{array}{r}15.7 \\
{[7]}\end{array}$ & 16.6 & 3.5 & 4.5 & $\begin{array}{r}2.8 \\
{[22]}\end{array}$ & $\begin{array}{r}2.2 \\
{[21]}\end{array}$ & 12.3 & 7.6 & 0.4 \\
\hline 4 & $\begin{array}{r}49.7 \\
{[6]}\end{array}$ & $\begin{array}{l}2.8 \\
{[5]}\end{array}$ & 12.0 & 0.8 & 3.5 & $\begin{array}{c}2.8 \\
{[5]}\end{array}$ & $\begin{array}{l}1.5 \\
{[5]}\end{array}$ & 14.8 & 2.1 & 0.7 \\
\hline 5 & $\begin{array}{r}48.3 \\
{[6]}\end{array}$ & $\begin{array}{r}14.6 \\
{[6]}\end{array}$ & 37.8 & 5.1 & 2.9 & $\begin{array}{l}2.4 \\
{[7]}\end{array}$ & & 20.8 & & \\
\hline
\end{tabular}

* Brackets enclose the number of days that measurements of urinary and fecal electrolyte excretion were made. Values represent averages for each period. 
adrenal venous blood was collected, aldosterone and corticosterone secretion rates were determined by methods described previously $(7,8)$.

In experiment $1 \mathrm{~A}$ ( $5 \mathrm{dogs})$, carotid artery denervation was performed bilaterally. In this procedure (hereafter referred to as cervical carotid denervation), the carotid sinus nerves were sectioned bilaterally, and the carotid sinuses, the adjacent $1 \mathrm{~cm}$ of the internal and external carotid arteries, and the common carotid arteries, including the thyrocarotid arterial junctions, were bilaterally stripped of adventitia, painted with 5 per cent phenol and washed with absolute ethanol. Two to 3 weeks later, thoracic inferior vena caval constriction was performed. Approximately 2 weeks after caval constriction, the right adrenolumbar vein was cannulated under $\mathrm{Na}$ pentobarbital anesthesia in 3 of the $5 \mathrm{dogs}$, and adrenal effluent was collected. Experiment 1B (3 dogs) differed from $1 \mathrm{~A}$ in that thoracic inferior vena caval constriction was performed 2 to 3 weeks before cervical carotid denervation, and collections of the adrenal venous blood were not made in these animals. In Experiment 1C ( 2 dogs), thoracic inferior vena caval constriction was followed 10 days later by aortic arch denervation. In this operation (hereafter referred to as aortic arch denervation), the ascending aorta, the aortic arch, the brachiocephalic artery, and the proximal two-thirds of the thoracic descending aorta were thoroughly stripped of adventitia, painted with 5 per cent phenol and washed with absolute ethanol.

Experiment 1D (5 dogs) was designed to study the combined effects of cervical carotid denervation, aortic arch denervation and left cervical vagotomy on $\mathrm{Na}$ excretion in dogs with thoracic inferior vena caval constriction, and to determine whether superimposed acute right cervical vagotomy and bilateral splanchnic nerve section affects the hypersecretion of aldosterone observed in these animals. Thoracic inferior vena caval constriction and denervation of the cervical carotid and aortic arch baroreceptor areas were performed in three stages at intervals of 6 to 10 days; the sequence of these procedures was varied in the $5 \mathrm{dogs}$, as indicated in Table V. After completion of electrolyte balance studies,
TABLE II

Aldosterone and corticosterone secretion after chronic thoracic caval constriction in dogs with bilateral denervation of the common carotid arteries, the carotid sinuses and the thyrocarotid arterial junctions

\begin{tabular}{ccc}
\hline \hline Dog & $\begin{array}{c}\text { Aldosterone } \\
\text { secretion }\end{array}$ & $\begin{array}{c}\text { corticosterone } \\
\text { secretion }\end{array}$ \\
\hline 1 & $\mu g / m i n$ & $\mu g / \min$ \\
& 0.10 & 3.0 \\
2 & 0.13 & 3.1 \\
& 0.30 & 4.9 \\
3 & 0.35 & 6.5 \\
& 0.30 & 7.6 \\
Dogs with chronic thoracic & 0.53 & 3.2 \\
caval constriction & 0.135 & 3.2 \\
stressed by laparotomy & \pm 0.056 & 3.1 \\
(n = 16) & & \\
Normal dogs stressed by & 0.024 & \\
laparotomy (n = 26) & \pm 0.017 & \pm 0.84 \\
\hline
\end{tabular}

the right adrenolumbar vein was cannulated under $\mathrm{Na}$ pentobarbital anesthesia in 4 of the dogs. After two groups of control samples of adrenal venous blood had been collected at 30-minute intervals, the right vagus nerve was sectioned at the level of the cricoid cartilage, and the splanchnic nerves were divided bilaterally at the point at which they emerge from beneath the crura of the diaphragm. In 3 of these 4 dogs, adrenal effluent was collected 60 to 90 minutes after splanchnic section and right vagotomy; in the fourth dog an indwelling catheter was placed in the right adrenolumbar vein, the abdominal incision was closed under sterile conditions, and adrenal effluent was collected 24 hours after the bilateral splanchnic nerve section and right vagotomy. In 1 dog it was anticipated that the control rate of aldosterone secretion would not be greatly elevated, since the inferior vena caval pressure had fallen to $120 \mathrm{~mm}$ of water at the time of adrenolumbar vein cannulation; therefore, to provide a stimulus for hypersecretion of aldosterone, 2 hours after splanchnic section and right vagotomy this

TABLE 111

Effect of bilateral denervation of the common carotid arteries, the carotid sinuses and the thyrocarotid arterial junctions on electrolyte excretion in dogs with thoracic inferior vena caval constriction

\begin{tabular}{|c|c|c|c|c|c|c|c|c|c|c|}
\hline \multirow[b]{3}{*}{ Dog } & \multicolumn{5}{|c|}{ After thoracic inferior vena caval constriction } & \multicolumn{5}{|c|}{$\begin{array}{l}\text { After thoracic inferior vena caval constriction } \\
\text { plus carotid denervation }\end{array}$} \\
\hline & \multicolumn{2}{|c|}{$\mathrm{Na}$ excretion } & \multicolumn{2}{|c|}{ K excretion } & \multirow{2}{*}{$\begin{array}{l}\text { Fecal } \\
\mathrm{Na} / \mathrm{K}\end{array}$} & \multicolumn{2}{|c|}{$\mathrm{Na}$ excretion } & \multicolumn{2}{|c|}{ K excretion } & \multirow{2}{*}{$\begin{array}{l}\text { Fecal } \\
\mathrm{Na} / \mathrm{K}\end{array}$} \\
\hline & Urine & Feces & Urine & Feces & & Urine & Feces & Urine & Feces & \\
\hline & \multicolumn{2}{|c|}{$m E q / d a y$} & \multicolumn{2}{|c|}{$m E q / d a y$} & & \multicolumn{2}{|c|}{$m E q / d a y$} & \multicolumn{2}{|c|}{$m E q / d a y$} & \\
\hline 6 & $\begin{array}{c}2.3 \\
{[6]}\end{array}$ & $\begin{array}{r}4.5 \\
{[6]}\end{array}$ & 15.0 & 2.5 & 1.8 & $\begin{array}{c}2.2 \\
{[6]}\end{array}$ & $\begin{array}{r}2.1 \\
{[6]}\end{array}$ & 16.0 & 5.4 & 0.4 \\
\hline 7 & $\begin{array}{c}2.8 \\
{[5]}\end{array}$ & $\begin{array}{l}8.4 \\
{[5]}\end{array}$ & 28.5 & 11.8 & 0.7 & $\begin{array}{l}2.6 \\
{[4]}\end{array}$ & $\begin{array}{c}3.4 \\
{[4]}\end{array}$ & 18.3 & 2.6 & 1.3 \\
\hline 8 & $\begin{array}{c}2.5 \\
{[3]}\end{array}$ & $\begin{array}{c}2.3 \\
{[3]}\end{array}$ & 4.0 & 20.0 & 0.1 & $\begin{array}{c}1.9 \\
{[5]}\end{array}$ & $\begin{array}{c}2.4 \\
{[5]}\end{array}$ & 4.1 & 8.0 & 0.3 \\
\hline
\end{tabular}


TABLE IV

Effect of aortic arch denervation on electrolyte excretion in dogs with thoracic inferior vena caval constriction

\begin{tabular}{|c|c|c|c|c|c|c|c|c|c|c|}
\hline \multirow[b]{3}{*}{ Dog } & \multicolumn{5}{|c|}{ After thoracic inferior vena caval constriction } & \multicolumn{5}{|c|}{ After caval constriction plus aortic denervation } \\
\hline & \multicolumn{2}{|c|}{$\mathrm{Na}$ excretion } & \multicolumn{2}{|c|}{ K excretion } & \multirow{2}{*}{$\begin{array}{l}\text { Fecal } \\
\mathrm{Na} / \mathrm{K}\end{array}$} & \multicolumn{2}{|c|}{$\mathrm{Na}$ excretion } & \multicolumn{2}{|c|}{$\mathrm{K}$ excretion } & \multirow{2}{*}{$\begin{array}{l}\text { Fecal } \\
\mathrm{Na} / \mathrm{K}\end{array}$} \\
\hline & Urine & Feces & Urine & Feces & & Urine & Feces & Urine & Feces & \\
\hline & \multicolumn{2}{|c|}{$m E q / d a y$} & \multicolumn{2}{|c|}{$m E q / d a y$} & & \multicolumn{2}{|c|}{$m E q / d a y$} & \multicolumn{2}{|c|}{$m E q / d a y$} & \\
\hline 9 & $\begin{array}{l}2.8 \\
{[3]}\end{array}$ & $\begin{array}{r}1.9 \\
{[3]}\end{array}$ & 18.6 & 3.2 & 0.6 & $\begin{array}{r}2.6 \\
{[7]}\end{array}$ & $\begin{array}{r}1.0 \\
{[7]}\end{array}$ & 19.8 & 2.4 & 0.4 \\
\hline 10 & $\begin{array}{l}2.5 \\
{[3]}\end{array}$ & $\begin{array}{l}1.3 \\
{[3]}\end{array}$ & 20.7 & 2.5 & 0.5 & $\begin{array}{r}2.9 \\
{[3]}\end{array}$ & $\begin{array}{c}0.8 \\
{[7]}\end{array}$ & 22.7 & 6.3 & 0.1 \\
\hline
\end{tabular}

animal was subjected to acute hemorrhage with rapid removal of $250 \mathrm{ml}$ of blood via the femoral vein. Adrenal venous blood was collected 35 to 50 minutes later.

In Experiment 2 ( 7 dogs), to test further the hypothesis that baroreceptors in the carotid arterial tree are involved in regulation of aldosterone secretion, the acute effects of bilateral low cervical common carotid arterial constriction on aldosterone and corticosterone secretion were studied. After cannulation of the right adrenolumbar vein under $\mathrm{Na}$ pentobarbital anesthesia, ligatures were placed loosely around the common carotid arteries low in the neck proximal to the thyrocarotid arterial junction; in 5 of the 7 dogs, cannulae were placed in the lingual arteries bilaterally. Two groups of control samples of adrenal venous blood were collected at approximately 30-minute intervals, except in Dog 1 , in which the interval between control periods was 12 minutes. After control collections, the carotid arteries were constricted proximally, and adrenal effluent was collected 40 to 70 minutes after carotid constriction. All blood removed during Experiments 2 and 3 was immediately replaced with homologous transfusions. Aortic and lingual arterial pressures were measured with Statham strain gage transducers and recorded continuously on a Sanborn recorder.

Experiment 3 consisted of two acute studies designed

TABLE V

Effects of denervation of the common carotid arteries, the carotid sinuses and the aortic arch, and left vagotomy on electrolyte excretion in dogs with thoracic inferior vena caval constriction

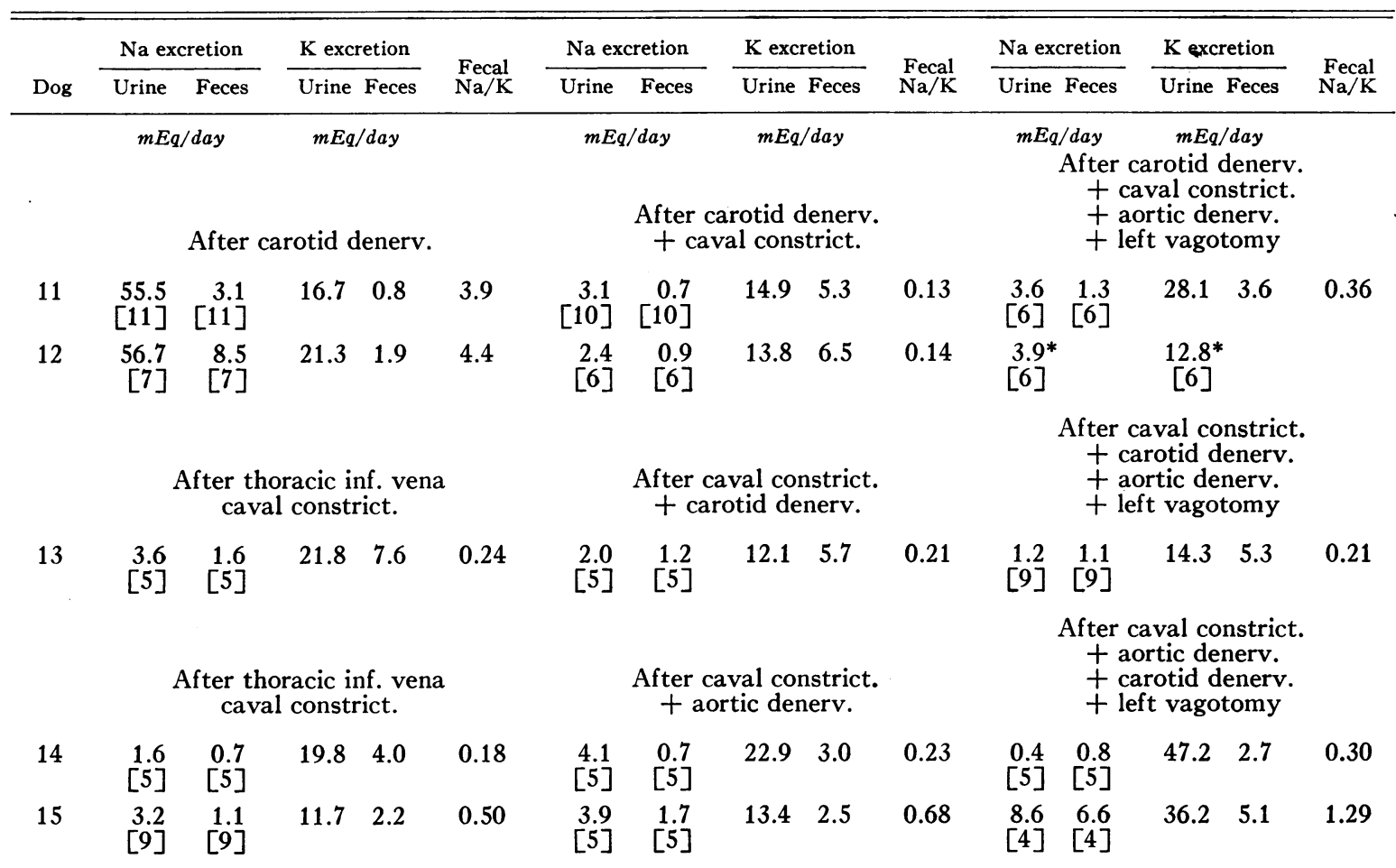

* These figures in Dog 12 represent the average Na and $\mathrm{K}$ excretion for Days 23-28 inclusive (Figure 1). 


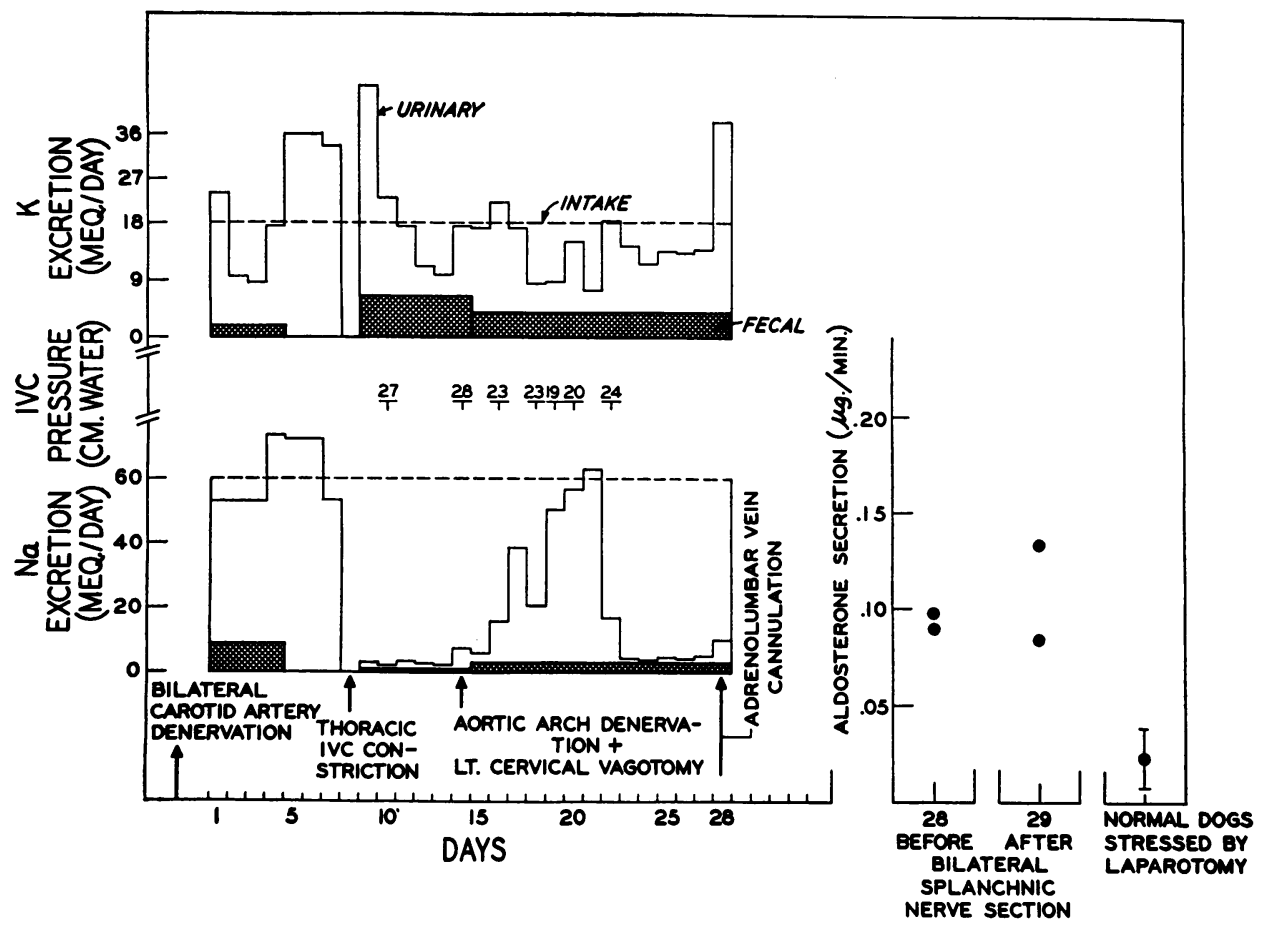

Fig. 1. Effects of bilateral Cervical Carotid denervation, thoracic inferior vena caval CONSTRICTION, AORTIC ARCH DENERVATION AND LEFT CERVICAL VAGOTOMY ON NA AND $\mathrm{K}$ EXCRETION, AND EFFECTS OF SUPERIMPOSED BILATERAL SPLANCHNIC NERVE SECTION AND RIGHT CERVICAL VAGOTOMY ON ALDOSTERONE SECRETION. Observe the marked increase in $\mathrm{Na}$ excretion concurrent with the fall in inferior vena caval pressure following aortic arch denervation and left cervical vagotomy, and the subsequent recurrence of almost complete $\mathrm{Na}$ retention concomitant with a spontaneous increase in inferior vena caval pressure (Dog 12 of Tables V and VI).

to examine the possibility that baroreceptors in the splanchnic circulation play a major role in regulation of aldosterone secretion. After cannulation of the right adrenolumbar vein under $\mathrm{Na}$ pentobarbital anesthesia, ligatures were placed loosely around the base of the celiac axis and the superior mesenteric artery, and cannulae were placed in secondary branches of these arteries. After two control collections of adrenal venous blood at 30-minute intervals, the ligatures were tightened to the extent that mean pressures in the celiac and superior mesenteric arteries fell to approximately one-half of the mean aortic pressure. One hour to 70 minutes after constriction of these arteries, adrenal venous blood was again collected for aldosterone and corticosterone determinations. Pressures in the aorta and in secondary branches of the celiac axis and the superior mesenteric artery were recorded continuously as in Experiment 2.

\section{RESULTS}

Experiment 1A. Thoracic inferior vena caval constriction after cervical carotid deneriation. All animals achieved $\mathrm{Na}$ balance within 3 days after cervical carotid denervation. In every instance thoracic inferior vena caval constriction was followed by marked $\mathrm{Na}$ retention, both fecal and urinary, and rapid accumulation of ascitic fluid (Table I). In the animals in which adrenal venous blood was collected (Dogs 1-3 of Table I), the rate of aldosterone secretion was greatly increased over the level observed in normal dogs stressed by laparotomy (Table II) and was as high as or higher than the levels previously observed (7) in animals with intact baroreceptor areas, which had been subjected to chronic thoracic inferior vena caval constriction.

Experiment $1 B$. Cervical carotid denervation subsequent to thoracic inferior vena caval constriction. After thoracic inferior vena caval constriction, all animals showed marked $\mathrm{Na}$ retention and very low fecal $\mathrm{Na} / \mathrm{K}$ ratios (9). Cervical carotid denervation had no effect on the virtually complete $\mathrm{Na}$ retention or on the low fecal $\mathrm{Na} / \mathrm{K}$ ratio in any of the three $\operatorname{logs}$ (Table III).

Experiment $1 C$. Aortic arch denervation subsequent to thoracic inferior vena caval constric- 
tion. Denervation of the ascending aorta, the aortic arch, the proximal two-thirds of the descending thoracic aorta and the brachiocephalic artery had no demonstrable effect on the marked $\mathrm{Na}$ retention and the low fecal $\mathrm{Na} / \mathrm{K}$ ratio in dogs with thoracic inferior vena caval constriction (Table IV).

Experiment 1D. Cervical carotid denervation, aortic arch denervation, bilateral cervical vagotomy and bilateral splanchnic nerve section after thoracic caval constriction. Combined cervical carotid denervation, aortic arch denervation and left cervical vagotomy had no consistent effect on the marked $\mathrm{Na}$ retention and the low fecal $\mathrm{Na} / \mathrm{K}$ ratio secondary to thoracic inferior vena caval constriction (Table V). In Dog 11, in which thoracic inferior vena caval constriction was performed 2 weeks after cervical carotid denervation, subsequent aortic arch denervation and right vagotomy failed to influence the $\mathrm{Na}$ retention (Table V); inferior vena caval pressure in this dog remained consistently above $200 \mathrm{~mm}$ of water for the 16 days of observations that followed thoracic caval constriction. In Dog $12, \mathrm{Na}$ retention was almost complete after thoracic inferior vena caval constriction superimposed upon cervical carotid denervation. A definite increase in $\mathrm{Na}$ excretion was observed, however, 2 days after aortic arch denervation and left vagotomy (Figure 1); $\mathrm{Na}$ excretion reached a maximum of $60 \mathrm{mEq}$ on the seventh day after aortic denervation, after which virtually complete $\mathrm{Na}$ retention again occurred and continued for the remaining 7 days of observations. It is noteworthy that a fall in inferior vena caval pressure (from a maximum of 276 to a minimum of $190 \mathrm{~mm}$ of water) occurred following aortic denervation, concomitant with the increase in $\mathrm{Na}$ excretion, and that a spontaneous increase in venous pressure was observed concurrent with the restoration of $\mathrm{Na}$ retention. In Dog 13, neither cervical carotid denervation nor superimposed aortic arch denervation and left vagotomy influenced the marked fecal and urinary $\mathrm{Na}$ retention secondary to thoracic inferior vena caval constriction (Figure 2); inferior vena caval pressure remained consistently

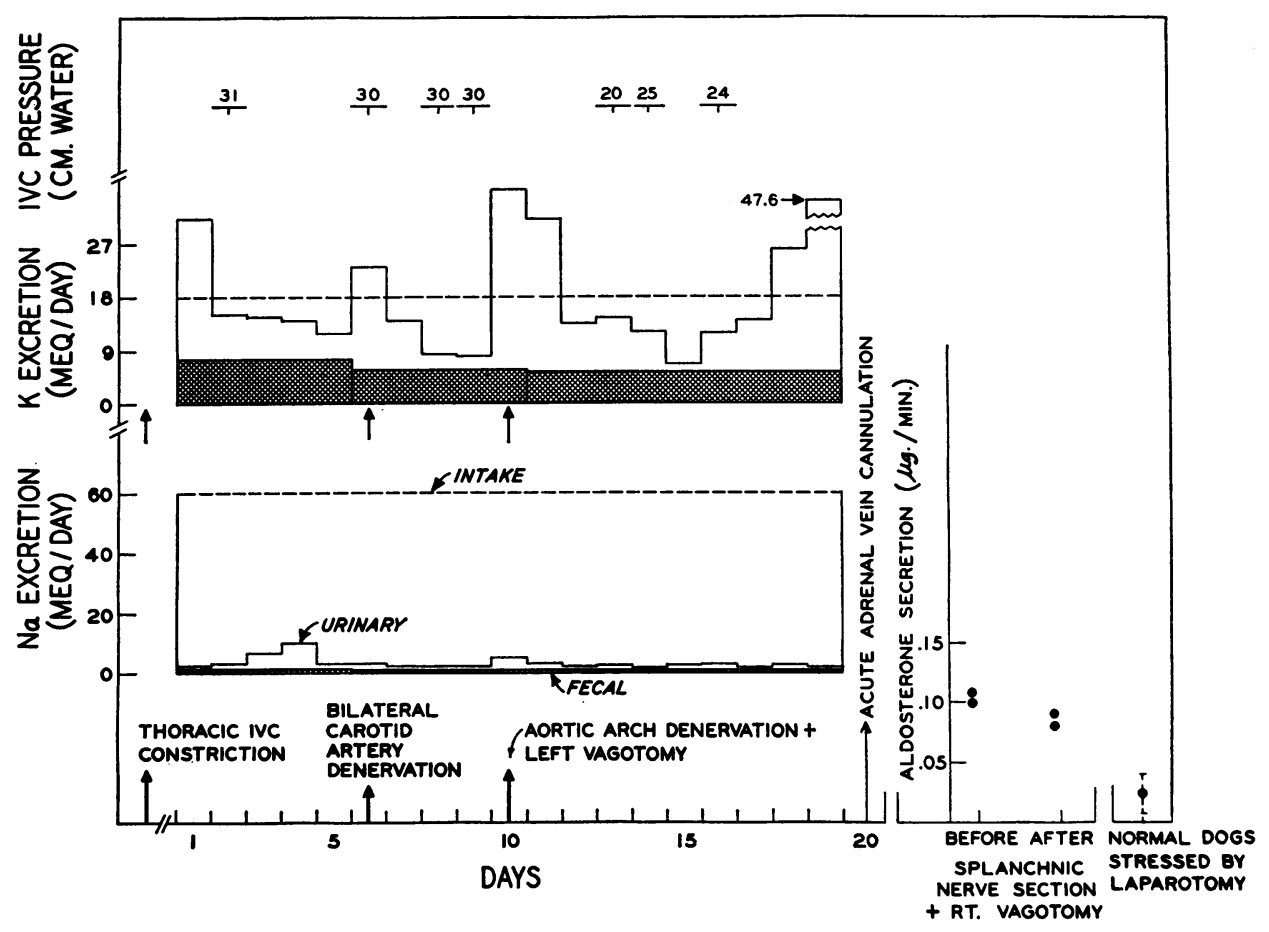

Fig. 2. Effects of bilateral cervical carotid denervation, aortic arch denervation and LEFT CERVICAL VAGOTOMY ON NA AND $\mathrm{K}$ EXCRETION IN A DOG WITH THORACIC INFERIOR VENA CAVAL CONSTRICTION, AND EFFECTS OF SUBSEQUENT BILATERAL SPLANCHNIC NERVE SECTION AND RIGHT CERVICAL VAGOTOMY ON ALDOSTERONE SECRETION RATE IN THE SAME DOG (DOG 13 OF TABLES V AND VI). 
TABLE VI

Effects of bilateral splanchnic nerve section and right cervical vagotomy on aldosterone and corticosterone secretion rates in dogs with chronic thoracic inferior vena caval constriction, chronic denervation of the cervical carotid and aortic arch baroreceptor areas and left cervical vagotomy

\begin{tabular}{|c|c|c|c|c|}
\hline Dog & Time* & $\begin{array}{l}\text { Aldosterone } \\
\text { secretion }\end{array}$ & $\begin{array}{l}\text { Corticosterone } \\
\text { secretion }\end{array}$ & $\begin{array}{l}\text { Adrenal blood } \\
\text { flow }\end{array}$ \\
\hline & $\min$ & $\mu g / \min$ & $\mu g / \min$ & $m l / \min$ \\
\hline \multirow[t]{4}{*}{12} & 0 & 0.10 & 2.2 & 3.4 \\
\hline & 10 & 0.09 & 1.4 & 3.2 \\
\hline & $\begin{array}{l}20 \text { Right cervical vagotomy and bilateral } \\
\text { splanchnic nerve section }\end{array}$ & & & \\
\hline & $\begin{array}{l}24 \mathrm{hrs} \\
24 \mathrm{hrs}\end{array}$ & $\begin{array}{l}0.08 \\
0.13\end{array}$ & $\begin{array}{l}0.5 \\
0.9\end{array}$ & $\begin{array}{l}1.1 \\
1.9\end{array}$ \\
\hline \multirow[t]{3}{*}{13} & $\begin{array}{r}0 \\
10\end{array}$ & $\begin{array}{l}0.10 \\
0.11\end{array}$ & $\begin{array}{l}1.9 \\
1.9\end{array}$ & $\begin{array}{l}3.3 \\
3.4\end{array}$ \\
\hline & $\begin{array}{l}15 \text { Right cervical vagotomy and bilateral } \\
\text { splanchnic nerve section }\end{array}$ & & & \\
\hline & $\begin{array}{l}60 \\
70\end{array}$ & $\begin{array}{l}0.08 \\
0.09\end{array}$ & $\begin{array}{l}1.1 \\
1.2\end{array}$ & $\begin{array}{l}1.5 \\
1.8\end{array}$ \\
\hline \multirow[t]{3}{*}{14} & $\begin{array}{r}0 \\
10\end{array}$ & $\begin{array}{l}0.14 \\
0.20\end{array}$ & $\begin{array}{l}1.6 \\
4.1\end{array}$ & $\begin{array}{l}3.0 \\
4.0\end{array}$ \\
\hline & $\begin{array}{l}15 \text { Right cervical vagotomy and bilateral } \\
\text { splanchnic nerve section }\end{array}$ & & & \\
\hline & $\begin{array}{l}100 \\
105\end{array}$ & $\begin{array}{l}0.14 \\
0.12\end{array}$ & $\begin{array}{l}1.4 \\
1.3\end{array}$ & $\begin{array}{l}4.4 \dagger \\
3.3\end{array}$ \\
\hline \multirow[t]{5}{*}{15} & $\begin{array}{l}0 \\
5\end{array}$ & $\begin{array}{l}0.04 \\
0.03\end{array}$ & $\begin{array}{l}1.5 \\
1.8\end{array}$ & $\begin{array}{l}3.9 \\
3.6\end{array}$ \\
\hline & $\begin{array}{l}15 \text { Right cervical vagotomy and bilateral } \\
\text { splanchnic nerve section }\end{array}$ & & & \\
\hline & $\begin{array}{l}110 \\
115\end{array}$ & $\begin{array}{l}0.04 \\
0.05\end{array}$ & $\begin{array}{l}1.1 \\
1.1\end{array}$ & $\begin{array}{l}4.0 \dagger \\
3.7\end{array}$ \\
\hline & 120 Acute hemorrhage $(250 \mathrm{ml})$ & & & \\
\hline & $\begin{array}{l}155 \\
160 \\
170\end{array}$ & $\begin{array}{l}0.11 \\
0.07 \\
0.08\end{array}$ & $\begin{array}{l}1.4 \\
1.1 \\
0.9\end{array}$ & $\begin{array}{l}4.6 \\
4.0 \\
1.9\end{array}$ \\
\hline \multicolumn{2}{|c|}{ Normal dogs stressed by laparotomy $(n=26)$} & $\begin{array}{r}0.024 \\
\pm 0.017\end{array}$ & $\begin{array}{r}2.34 \\
\pm 0.84\end{array}$ & $\begin{array}{r}2.9 \\
\pm 0.7\end{array}$ \\
\hline \multicolumn{2}{|c|}{$\begin{array}{l}\text { Dogs with chronic thoracic caval constriction stressed } \\
\text { by laparotomy }(n=16)\end{array}$} & $\begin{array}{r}0.135 \\
\pm 0.056\end{array}$ & $\begin{array}{r}3.1 \\
\pm 1.8\end{array}$ & \\
\hline
\end{tabular}

* In Dog 12, adrenal vein blood was collected by chronic catheter 24 hours after right vagotomy and bilateral splanchnic nerve section. In Dogs 13-15, blood was collected between 45 and 155 minutes after right vagotomy and bilateral splanchnic nerve section, as indicated.

† Blood pressure was maintained with norepinephrine after splanchnic nerve section in Dogs 14 and 15.

above $205 \mathrm{~mm}$ of water in this animal, although a transient fall in vena caval pressure occurred on the third day after aortic denervation. In Dog 14, neither aortic arch denervation nor superimposed cervical carotid denervation and left vagotomy affected the almost complete $\mathrm{Na}$ retention that resulted from thoracic inferior vena caval constriction; inferior vena caval pressure ranged between 230 and $240 \mathrm{~mm}$ of water in this animal. In Dog 15, a slight increase in urinary $\mathrm{Na}$ excretion (to a maximum of $11.9 \mathrm{mEq}$ per day) and a more marked increase in fecal $\mathrm{Na}$ ex- cretion (to a maximum of $6.6 \mathrm{mEq}$ per day) were noted after cervical carotid denervation and left vagotomy had been superimposed upon aortic arch denervation; however, this animal continued to show a strongly positive $\mathrm{Na}$ balance and to accumulate ascitic fluid throughout the period of observation. It is noteworthy that venous pressure decreased from 246 to $200 \mathrm{~mm}$ of water on the day following aortic denervation, concurrent with the increase in $\mathrm{Na}$ excretion, and persisted at the lower level throughout the remainder of the period of observations. 
TABLE VII

Aldosterone and corticosterone secretion rates, adrenal blood flows and mean aortic pressures before and 40 to 70 minutes after bilateral proximal common carotid arterial constriction

\begin{tabular}{|c|c|c|c|c|c|}
\hline Dog & Time & $\begin{array}{l}\text { Aldosterone } \\
\text { secretion }\end{array}$ & $\begin{array}{c}\text { Corticosterone } \\
\text { secretion }\end{array}$ & $\begin{array}{l}\text { Adrenal blood } \\
\text { flow }\end{array}$ & $\begin{array}{l}\text { Mean aortic } \\
\text { blood pres. }\end{array}$ \\
\hline & $\min$ & $\mu \mathrm{g} / \min$ & $\mu g / \min$ & $m l / m i n$ & $m m \mathrm{Hg}$ \\
\hline \multirow[t]{3}{*}{1} & $\begin{array}{r}0 \\
12\end{array}$ & $\begin{array}{l}0.014 \\
0.031\end{array}$ & $\begin{array}{l}1.8 \\
1.4\end{array}$ & $\begin{array}{l}2.5 \\
1.9\end{array}$ & $\begin{array}{l}92 \\
90\end{array}$ \\
\hline & 23 & & & & \\
\hline & $\begin{array}{l}80 \\
93\end{array}$ & $\begin{array}{l}0.039 \\
0.032\end{array}$ & $\begin{array}{l}1.2 \\
1.3\end{array}$ & $\begin{array}{l}1.5 \\
2.2\end{array}$ & $\begin{array}{r}105 \\
98\end{array}$ \\
\hline \multirow[t]{3}{*}{2} & $\begin{array}{r}0 \\
32\end{array}$ & $\begin{array}{l}0.022 \\
0.026\end{array}$ & $\begin{array}{l}2.9 \\
3.0\end{array}$ & $\begin{array}{l}3.4 \\
3.0\end{array}$ & $\begin{array}{l}125 \\
120\end{array}$ \\
\hline & 37 & & & & \\
\hline & $\begin{array}{l}76 \\
90\end{array}$ & $\begin{array}{l}0.025 \\
0.028\end{array}$ & $\begin{array}{l}2.8 \\
3.8\end{array}$ & $\begin{array}{l}2.7 \\
2.3\end{array}$ & $\begin{array}{l}128 \\
140\end{array}$ \\
\hline \multirow[t]{3}{*}{3} & $\begin{array}{r}0 \\
26\end{array}$ & $\begin{array}{l}0.008 \\
0.005\end{array}$ & $\begin{array}{l}2.9 \\
1.6\end{array}$ & $\begin{array}{l}4.3 \\
4.0\end{array}$ & $\begin{array}{l}120 \\
122\end{array}$ \\
\hline & 35 & & & & \\
\hline & $\begin{array}{l}85 \\
90\end{array}$ & $\begin{array}{l}0.009 \\
\\
0.005\end{array}$ & $\begin{array}{l}2.7 \\
1.8\end{array}$ & $\begin{array}{l}5.3 \\
4.8\end{array}$ & $\begin{array}{l}140 \\
150\end{array}$ \\
\hline \multirow[t]{3}{*}{4} & $\begin{array}{r}0 \\
30\end{array}$ & $\begin{array}{l}0.011 \\
0.014\end{array}$ & $\begin{array}{l}0.7 \\
0.8\end{array}$ & $\begin{array}{l}3.3 \\
2.4\end{array}$ & $\begin{array}{l}125 \\
125\end{array}$ \\
\hline & 41 & & & & \\
\hline & $\begin{array}{r}97 \\
101\end{array}$ & $\begin{array}{l}0.019 \\
0.020\end{array}$ & $\begin{array}{l}2.1 \\
2.5\end{array}$ & $\begin{array}{l}2.3 \\
2.3\end{array}$ & $\begin{array}{l}187 \\
157\end{array}$ \\
\hline \multirow[t]{3}{*}{5} & $\begin{array}{r}0 \\
32\end{array}$ & $\begin{array}{l}0.010 \\
0.022\end{array}$ & $\begin{array}{l}3.6 \\
2.4\end{array}$ & $\begin{array}{l}3.8 \\
2.3\end{array}$ & $\begin{array}{l}140 \\
140\end{array}$ \\
\hline & 57 & & & & \\
\hline & $\begin{array}{l}118 \\
126\end{array}$ & $\begin{array}{l}0.017 \\
0.018\end{array}$ & $\begin{array}{l}3.0 \\
3.0\end{array}$ & $\begin{array}{l}2.3 \\
2.3\end{array}$ & $\begin{array}{l}143 \\
150\end{array}$ \\
\hline \multirow[t]{3}{*}{6} & $\begin{array}{r}0 \\
39\end{array}$ & $\begin{array}{l}0.010 \\
0.020\end{array}$ & $\begin{array}{l}0.8 \\
1.5\end{array}$ & $\begin{array}{l}2.0 \\
2.3\end{array}$ & $\begin{array}{l}104 \\
112\end{array}$ \\
\hline & 53 & & & & \\
\hline & $\begin{array}{l}103 \\
112\end{array}$ & $\begin{array}{l}0.030 \\
0.035\end{array}$ & $\begin{array}{l}1.7 \\
1.9\end{array}$ & $\begin{array}{l}2.4 \\
2.2\end{array}$ & $\begin{array}{l}165 \\
150\end{array}$ \\
\hline \multirow[t]{3}{*}{7} & $\begin{array}{r}0 \\
30\end{array}$ & $\begin{array}{l}0.034 \\
0.044\end{array}$ & $\begin{array}{l}4.1 \\
4.4\end{array}$ & $\begin{array}{l}5.8 \\
6.0\end{array}$ & $\begin{array}{l}124 \\
125\end{array}$ \\
\hline & 35 & & & & \\
\hline & $\begin{array}{l}105 \\
108\end{array}$ & $\begin{array}{l}0.046 \\
0.045\end{array}$ & $\begin{array}{l}2.3 \\
1.9\end{array}$ & $\begin{array}{l}5.2 \\
4.3\end{array}$ & $\begin{array}{l}150 \\
145\end{array}$ \\
\hline Av., 1st control period & & 0.016 & 2.3 & 3.6 & 116 \\
\hline Av., 2nd control period & & 0.023 & 2.0 & 3.1 & 118 \\
\hline Av., after carotid constrict. & & 0.027 & 2.1 & 3.0 & 146 \\
\hline $\begin{array}{l}\text { Normal dogs stressed by } \\
\text { laparotomy }(\mathrm{n}=26)\end{array}$ & & $\begin{array}{r}0.024 \\
\pm 0.017\end{array}$ & $\begin{array}{r}2.34 \\
\pm 0.84\end{array}$ & $\begin{array}{r}2.9 \\
\pm 0.7\end{array}$ & \\
\hline
\end{tabular}

In Dogs 12, 13, and 14 the control aldosterone secretion rates were uniformly elevated (Table $\mathrm{VI}$ ), and were in the range previously observed in dogs with intact baroreceptor areas subjected to thoracic inferior vena caval constriction (7). Superimposed acute right vagal section and bilateral splanchnic nerve section had no effect on the hypersecretion of aldosterone in any of the three dogs, despite a marked fall in mean arterial pressure and a resultant decrease in adrenal blood flow in Dogs 12 and 13 (Table VI). In Dog 14, mean arterial pressure and adrenal blood flow were maintained at the control levels by means of a constant infusion of norepinephrine. In Dog 15 , in which the venous pressure had fallen to $120 \mathrm{~mm}$ of water at the time of adrenolumbar vein 
cannulation, the control aldosterone secretion rate was only slightly elevated and was not altered by acute right vagal section and bilateral splanchnic nerve section, but a definite increase in aldosterone secretion was observed after superimposed acute hemorrhage in this animal (Table VI). In all four dogs, control corticosterone secretion rates were within the range previously observed following laparotomy in both normal dogs and in animals with thoracic inferior vena caval constriction (7). After right cervical vagotomy and splanchnic nerve section, a slight decrease in the rate of corticosterone secretion was consistently noted.

Experiment 2. Acute effects of bilateral common carotid arterial constriction on aldosterone secretion. Low cervical constriction of the common carotid artery elicited the Hering reflex, causing an increase in systemic arterial pressure in six of the seven dogs, a transient decrease in mean lingual arterial pressure in all animals and a sustained fall in lingual arterial pulse pressure in all dogs. The average decrease in lingual arterial pulse pressure was from 27 to $7 \mathrm{~mm} \mathrm{Hg}$. The average rate of aldosterone secretion of 0.027 $\mu \mathrm{g}$ per minute after carotid constriction was slightly higher than the average control value of $0.020 \mu \mathrm{g}$ per minute $(t=2.91 ; 0.05>\mathrm{p}>0.02$; Table VII). However, the rates of aldosterone production for all periods in all dogs were within the range observed for normal animals stressed by adrenolumbar vein cannulation (mean, $0.024 \pm$ $0.017 \mu \mathrm{g}$ per minute, SD). It is noteworthy that the values for aldosterone secretion during the second control period were higher than those for the first control period in six of the seven dogs $(t=2.61 ; 0.05>\mathrm{p}>0.02)$. In five of the seven dogs (1-3, 5 and 7 , Table VII), the aldosterone secretion rate during the second control period was as high as the values observed after carotid constriction; in only two dogs (4 and 6, Table VII) were the experimental aldosterone secretion rates greater than the values obtained during the second control period. With the exception of Dog 4 and the first period for Dog 6, the control corticosterone secretion rates were at the high level charactistic of normal dogs stressed by adrenolumbar vein cannulation. In Dog 4, corticosterone production was clearly increased after carotid constriction, and in Dog 6 the two experimental values for corticosterone output were higher than the control values. This finding suggests increased release of ACTH after carotid constriction in Dogs 4 and 6, the two animals in which the values for aldosterone secretion during carotid constriction were higher than the control values.

Experiment 3. Acute effects of simultaneous constriction of celiac and superior mesenteric arteries on aldosterone secretion. The celiac and

TABLE VIII

Effects of proximal constriction of the celiac axis and the superior mesenteric artery on aldosterone and corticosterone secretion rates in normal dogs

\begin{tabular}{|c|c|c|c|c|c|c|c|}
\hline Dog & Time & $\begin{array}{l}\text { Aldosterone } \\
\text { secretion }\end{array}$ & $\begin{array}{l}\text { Corticosterone } \\
\text { secretion }\end{array}$ & $\begin{array}{l}\text { Adrenal } \\
\text { blood } \\
\text { flow }\end{array}$ & $\begin{array}{l}\text { Mean } \\
\text { aortic } \\
\text { pressure }\end{array}$ & $\begin{array}{c}\text { Mean } \\
\text { celiac } \\
\text { arterial } \\
\text { pressure }\end{array}$ & $\begin{array}{c}\text { Mean } \\
\text { superior } \\
\text { mesenteric } \\
\text { pressure }\end{array}$ \\
\hline \multirow[t]{3}{*}{1} & $\begin{array}{r}\min \\
0 \\
24\end{array}$ & $\begin{array}{r}\mu g / \min \\
0.028 \\
0.012\end{array}$ & $\begin{array}{c}\mu \mathrm{g} / \mathrm{min} \\
3.4 \\
3.2\end{array}$ & $\begin{array}{c}m l / m i n \\
3.4 \\
2.5\end{array}$ & $\begin{array}{c}m m H g \\
120\end{array}$ & $\begin{array}{c}m m H g \\
117\end{array}$ & $\begin{array}{c}m m H g \\
117\end{array}$ \\
\hline & $\begin{array}{l}34 \text { Constriction } \\
44\end{array}$ & & & & 135 & 85 & 75 \\
\hline & $\begin{array}{l}100 \\
105\end{array}$ & $\begin{array}{l}0.019 \\
0.026\end{array}$ & $\begin{array}{l}2.4 \\
2.6\end{array}$ & $\begin{array}{l}2.0 \\
2.1\end{array}$ & $\begin{array}{l}136 \\
142\end{array}$ & $\begin{array}{l}62 \\
55\end{array}$ & $\begin{array}{l}92 \\
70\end{array}$ \\
\hline \multirow[t]{3}{*}{2} & $\begin{array}{r}0 \\
40\end{array}$ & $\begin{array}{l}0.024 \\
0.028\end{array}$ & $\begin{array}{l}0.9 \\
1.4\end{array}$ & $\begin{array}{l}2.0 \\
2.0\end{array}$ & $\begin{array}{l}130 \\
135\end{array}$ & $\begin{array}{l}125 \\
128\end{array}$ & $\begin{array}{l}125 \\
125\end{array}$ \\
\hline & $\begin{array}{l}48 \text { Constriction } \\
58\end{array}$ & & & & 155 & 70 & 80 \\
\hline & $\begin{array}{l}110 \\
114\end{array}$ & $\begin{array}{l}0.026 \\
0.024\end{array}$ & $\begin{array}{l}1.2 \\
1.2\end{array}$ & $\begin{array}{l}2.1 \\
2.2\end{array}$ & $\begin{array}{l}155 \\
165\end{array}$ & $\begin{array}{r}75 \\
125\end{array}$ & $\begin{array}{r}75 \\
120\end{array}$ \\
\hline $\begin{array}{l}\text { Normal dogs stressed by } \\
\text { laparotomy }(n=26)\end{array}$ & & $\begin{array}{r}0.024 \\
\pm 0.017\end{array}$ & $\begin{array}{r}2.34 \\
\pm 0.84\end{array}$ & $\begin{array}{r}2.9 \\
\pm 0.7\end{array}$ & & & \\
\hline
\end{tabular}


superior mesenteric arteries were constricted to the extent that mean pressures in the secondary branches of these vessels decreased to one-half to two-thirds of the control mean arterial pressures; concomitant with the fall in mean arterial pressure, a marked decrease in pulse pressure occurred with an average decrease from 30 to 10 $\mathrm{mm} \mathrm{Hg}$. Constriction of the celiac and superior mesenteric arteries resulted in an increase in mean aortic pressure in both dogs; an average increase of $20 \mathrm{~mm} \mathrm{Hg}$ was observed within 2 minutes after constriction of the vessels, and this increase was sustained throughout the period of constriction. Control aldosterone secretion rates in both animals were in the range observed in normal animals stressed by laparotomy, and no change occurred within 70 minutes after constriction of the celiac and superior mesenteric arteries (Table VIII). Control corticosterone secretion rates were likewise in the range observed in normal animals stressed by adrenolumbar vein cannulation; no consistent change in corticosterone secretion occurred after celiac and superior mesenteric arterial constriction (Table VIII).

\section{DISCUSSION}

Several investigators have postulated that aldosterone secretion is regulated by a neural mechanism which involves a peripheral receptor and central nervous system integration, but the components of this hypothetical system have remained elusive. Epstein and co-workers (1), on the basis of observations that a "tendency toward inadequate filling of the systemic arterial tree" is a factor common to those circulatory states in which the kidneys retain abnormal amounts of $\mathrm{Na}$, suggested that receptors mediating $\mathrm{Na}$ conservation are located in the arterial tree. Barger and colleagues (5) pointed out that $\mathrm{Na}$ retention is found in a number of diverse conditions in which carotid sinus baroreceptor activity is decreased and suggested that carotid sinus baroreceptors may initiate impulses which provide the afferent limb of the reflex arc responsible for aldosterone secretion. Bartter and colleagues (6) have proposed that receptors located at the thyrocarotid arterial junction initiate impulses which lead to hypersecretion of aldosterone after thoracic caval constriction and after common carotid arterial constriction in the dog. Gann and
Bartter (10) reported that denervation of the thyrocarotid arterial junction baroreceptor area produced an acute transient increase in the secretion rate of aldosterone, but that the aldosterone secretion rate was normal 1 week after the denervation procedure. Bartter and Gann (2) have further reported that interruption of afferent nervous pathways arising at the thyrocarotid arterial junction prevented an increase in aldosterone secretion rate following acute constriction of the thoracic inferior vena cava and that denervation of the thyrocarotid arterial junction in two dogs with ascites secondary to thoracic inferior vena caval constriction resulted in natriuresis.

The results of Experiment $1 \mathrm{~A}$ of the present study demonstrate that complete bilateral denervation of the carotid baroreceptor areas does not prevent the hypersecretion of aldosterone and the virtually complete $\mathrm{Na}$ retention which follow thoracic inferior vena caval constriction in the dog. These results are in agreement with those previously reported by Davis and co-workers (4). The most likely explanation for the results of Bartter and Gann (2), in which denervation of the thyrocarotid arterial junction was followed by natriuresis in two dogs with chronic thoracic inferior vena caval constriction, is that a spontaneous fall in inferior vena caval pressure occurred following the denervation in the two dogs reported. Although venous collateralization with a concurrent drop in venous pressure, natriuresis, and loss of ascitic fluid is a common occurrence in the dog with thoracic inferior vena caval constriction (personal observations), Bartter and Gann did not report measurements of venous pressure. In the acute studies of Gann and Bartter (10), in which aldosterone secretion appeared to increase as a result of thyrocarotid arterial denervation, no control observations were reported in which the nerve was not sectioned. Another interpretation of their data is that the surgery required for adrenolumbar vein cannulation and denervation stimulated the release of ACTH with a resultant transient increment in aldosterone secretion. In Experiment 2 of the present study, the frequent finding of an increase in aldosterone secretion rate between the first and second control periods is probably attributable to ACTH release secondary to laparotomy and adrenolumbar vein cannulation. 
Our results from proximal constriction of the common carotid artery support the findings of the above denervation experiments. After carotid constriction, a marked reduction in pulse pressure and a moderate to slight reduction in mean arterial pressure in the area of the carotid sinus and the thyrocarotid arterial junction occurred. A small increase in aldosterone production was observed in only two of seven animals, and the present data suggest that this increment was secondary to increased release of ACTH. These results are in contrast to the data of Bartter and co-workers (6) who reported that bilateral carotid constriction consistently increased aldosterone secretion in dogs with intact baroreceptor areas. A likely explanation for the findings of Bartter and associates is that the observed increase in aldosterone production was caused by increased release of ACTH. Consonant with this explanation is the report of Biglieri and Ganong (11); these investigators observed an elevation in the rate of aldosterone secretion after proximal common carotid constriction in the normal dog, but found that aldosterone production failed to increase after similar carotid arterial constriction in the hypophysectomized dog. On the basis of available evidence, it is concluded that if carotid arterial baroreceptors influence aldosterone secretion, the effect is mediated acutely via the ACTH mechanism. The small and inconsistent changes observed following carotid constriction in the present study make it doubtful that carotid arterial baroreceptors play a significant physiological role in the regulation of aldosterone secretion.

The results of Experiment $1 \mathrm{C}$ of the present study, in which denervation of the aortic arch had no effect on the observed $\mathrm{Na}$ retention in two dogs with chronic thoracic inferior vena caval constriction, demonstrate that the aortic arch baroreceptors are not essential to almost complete $\mathrm{Na}$ retention in the dog with caval constriction. The present results are consistent with the findings of Bartter and Gann (2) and of Davis and associates (4) that bilateral vagotomy with destruction of afferent fibers from the aortic arch baroreceptors failed to prevent the rise in aldosterone secretion that results from thoracic inferior vena caval constriction in the dog.

If arterial receptors responsible for hypersecretion of aldosterone originated in both the carotid and the aortic baroreceptor areas, then it is possible that compensation by the aortic receptors would prevent a protracted alteration in aldosterone secretion after denervation of the carotid baroreceptor areas. Such a compensatory mechanism by intact aortic baroreceptors has been shown to prevent a sustained rise in blood pressure after bilateral carotid sinus denervation (12, 13). To examine this possibility, the combined effects of denervation of both the carotid and the aortic baroreceptor areas on $\mathrm{Na}$ excretion in the dog with thoracic inferior vena caval constriction were investigated. The fact that $\mathrm{Na}$ retention continued unabated after this extensive denervation procedure in four of the five dogs (Table V) demonstrates clearly that baroreceptors in the aortic arch and the carotid arterial tree are not essential to the $\mathrm{Na}$ retention that results from thoracic inferior vena caval constriction in the dog. The most likely explanation for the transient increase in $\mathrm{Na}$ excretion in Dog 12 is that the observed natriuresis resulted from the transient fall in inferior vena caval pressure.

After the demonstration that neither aortic arch nor common carotid baroreceptor areas are essential to the $\mathrm{Na}$ retention secondary to thoracic caval constriction, the possible role of abdominal baroreceptors was investigated. The Pacinian corpuscles in proximity to the mesenteric arterial tree were found by Gammon and Bronk (14) to have a characteristic discharge of impulses influenced by blood volume, mean arterial pressure and pulse pressure; action potentials from these receptors were recorded from the splanchnic nerves. Heymans, Bouckaert, Farber and Hsu (15) later confirmed the presence of these baroreceptors in the mesenteric circulation. These abdominal baroreceptors decrease the rate of discharge of impulses under certain circumstances (e.g., hemorrhage) in which hypersecretion of aldosterone and $\mathrm{Na}$ retention have been observed. Thus, the abdominal baroreceptors, either alone or in conjunction with the cervical carotid and aortic arch baroreceptors, might possibly form the afferent limb of a nervous mechanism that regulates aldosterone secretion. If the splanchnic baroreceptors functioned in conjunction with the cervical carotid and aortic arch baroreceptors in the regulation of aldosterone secretion, then these abdominal baroreceptors might play a more im- 
portant role after denervation of the aortic arch and the carotid arterial tree; for it has been shown that the splanchnic baroreceptors in the dog exert a much greater effect on systemic arterial pressure after carotid sinus denervation and bilateral vagotomy (16). The present experimental results, however, demonstrate that bilateral splanchnic nerve section, with interruption of a major portion of the afferent impulses from abdominal baroreceptors, has no effect on the hypersecretion of aldosterone observed after chronic thoracic inferior vena caval constriction in dogs with chronic denervation of the cervical carotid and aortic arch baroreceptor areas. These observations are in accord with the data obtained from Experiment 3, in which marked reductions in mean arterial pressure and pulse pressure in the mesenteric arterial tree were without effect on the rate of aldosterone secretion. The report of Holzbauer and Vogt (17) that bilateral splanchnic nerve section in the dog prevented an increase in aldosterone secretion after acute hemorrhage has suggested that abdominal arterial receptors are essential to the increased aldosterone secretion that is observed after acute blood loss. It should be pointed out, however, that bilateral splanchnic nerve section results in a marked decrease in adrenal blood flow (see Dogs 12 and 13 of Table VI). If acute hemorrhage superimposed an additional reduction in arterial pressure and adrenal blood flow, this might curtail adrenocortical steroidogenesis and account for the failure of aldosterone secretion to increase in the experiments reported by Holzbauer and Vogt (17). The results obtained from Dog 15 of Experiment 1D, in which norepinephrine was used to maintain adrenal blood flow at control levels after bilateral splanchnic nerve section and subsequent hemorrhage, demonstrate that the animal maintained the ability to respond to hemorrhage by an increase in aldosterone secretion rate after cervical carotid denervation, aortic arch denervation, bilateral vagotomy and bilateral splanchnic nerve section.

\section{SUM MARY}

Extensive denervation of the central arterial tree, including both the cervical carotid and the aortic arch baroreceptor areas, failed to prevent the hypersecretion of aldosterone and virtually complete $\mathrm{Na}$ retention that results from thoracic inferior vena caval constriction in the dog, and superimposed bilateral vagotomy and bilateral splanchnic nerve section did not affect the increased secretion of aldosterone observed in these animals. After the denervation procedures, acute hemorrhage in one dog resulted in an increase in the rate of aldosterone secretion which was similar to that observed following hemorrhage in dogs with intact baroreceptor areas. Bilateral low cervical carotid arterial constriction resulted in an increase in aldosterone production in two of seven dogs; in both animals, the change appeared to be mediated via increased ACTH release. Simultaneous constriction of the celiac axis and the superior mesenteric artery had no effect on aldosterone secretion. These data offer no support for the concept that arterial baroreceptors constitute the afferent limb of a reflex arc concerned with the primary regulation of aldosterone secretion.

\section{REFERENCES}

1. Epstein, F. H., Post, R. S., and McDowell, M. The effect of an arteriovenous fistula on renal hemodynamics and electrolyte excretion. J. clin. Invest. 1953, 32, 233.

2. Bartter, F. C., and Gann, D. S. On the hemodynamic regulation of the secretion of aldosterone. Circulation 1960, 21, 1016.

3. Barger, A. C. The pathogenesis of sodium retention in congestive heart failure. Metabolism 1956, 5, 480.

4. Davis, J. O., Yankopoulos, N. A., and Holman, J. Chronic effects of carotid sinus denervation, cervical vagotomy and aortic depressor nerve section on aldosterone and sodium excretion. Amer. J. Physiol. 1959, 197, 207.

5. Barger, A. C., Muldowney, F. P., and Liebowitz, M. R. The role of the kidney in the pathogenesis of congestive heart failure. Circulation 1959, 20, 273.

6. Bartter, F. C., Mills, I. H., and Gann, D. S. Increase in aldosterone secretion by carotid artery constriction in the dog and its prevention by thyrocarotid arterial junction denervation. $\mathrm{J}$. clin. Invest. 1960, 39, 1330.

7. Yankopoulos, N. A., Davis, J. O., Kliman, B., and Peterson, R. E. Evidence that a humoral agent stimulates the adrenal cortex to secrete aldosterone in experimental secondary hyperaldosteronism. J. clin. Invest. 1959, 38, 1278. 
8. Kliman, B., and Peterson, R. E. Double isotope derivative assay of aldosterone in biological extracts. J. biol. Chem. 1960, 235, 1639.

9. Davis, J. O., and Howell, D. S. Mechanisms of fluid and electrolyte retention in experimental preparations in dogs. II. With thoracic inferior vena cava constriction. Circulat. Res. 1953, 1, 171.

10. Gann, D. S., and Bartter, F. C. Increase in aldosterone secretion by acute denervation of the thyrocarotid arterial junction. Amer. J. Physiol. 1960, 199, 193.

11. Biglieri, E. G., and Ganong, W. F. Effect of hypophysectomy on the adrenocortical response to bilateral carotid constriction. Physiologist 1960, 3 (Aug. 1960, no. 3), 21.

12. Heymans, C., and Neil, E. Reflexogenic Areas of the Cardiovascular System. London, Churchill, 1958.
13. Thomas, C. B. Experimental hypertension from section of moderator nerves. Bull. Johns Hopk. Hosp. 1944, 75, 355.

14. Gammon, G. D., and Bronk, D. W. Discharge of impulses from Pacinian corpuscles in the mesentery and its relation to vascular changes. Amer. J. Physiol. 1935, 114, 77.

15. Heymans, C., Bouckaert, J. J., Farber, S., and Hsu, T. Y. Spinal vasomotor reflexes associated with variations in blood pressure. Amer. J. Physiol. 1936, 117, 619.

16. Selkurt, E. E., and Rothe, C. F. Splanchnic baroreceptors in the dog. Amer. J. Physiol. 1960, 199, 335.

17. Holzbauer, M., and Vogt, M. Observations on the control of secretion of aldosterone. J. Physiol. (Lond.) 1959, 148, $13 \mathrm{P}$. 